DOI 10.31489/2021No1/29-33

UDC 54.057+548.3+546.562:47:713-31:654:311

\title{
SYNTHESIS AND X-RAY INVESTIGATION OF NOVEL NANOSTRUCTURED COPPER-ZINC MANGANITES OF LANTHANUM AND ALKALI METALS
}

\author{
Kasenov B.K. ${ }^{1}$, Kasenova Sh.B. ${ }^{1}$, Sagintaeva Zh.I. ${ }^{1}$, Nukhuly A., Turtubaeva M.O. ${ }^{2}$, \\ Bekturganov Zh.S. ${ }^{3}$, Zeinidenov A.K. ${ }^{3}$, Kuanyshbekov E.E. ${ }^{1}$, Issabaeva M.A. ${ }^{2}$ \\ ${ }^{1}$ Abishev Chemical-Metallurgical Institute, Karaganda, Kazakhstan \\ ${ }^{2}$ Toraighyrov Pavlodar University, Pavlodar, Kazakhstan \\ 3E.A. Buketov Karaganda University, Karaganda, Kazakhstan, kasenov1946@mail.ru
}

\begin{abstract}
The aim of this work is to synthesize new nanostructured copper-zinc lanthanum and alkaline metal manganites. Polycrystalline copper-zinc manganites of lanthanum and alkali metals were synthesized by the method of ceramic technology from lanthanum (III), copper (II), zinc (II), manganese (III) oxides, and lithium, sodium, and potassium carbonates in the range of 800-1200 ${ }^{\circ} \mathrm{C}$. Nanostructured particles were obtained by grinding the synthesized polycrystalline compounds at the «MM301» vibration mill of «Retsch» (Germany). By indexing $X$-ray images of nanostructured copper-zinc lanthanum and alkaline metal manganites, it was found that they crystallize in cubic syngony. Their lattice parameters are determined. There is a pattern in the change of the lattice parameters from the ionic radii of alkaline metals.
\end{abstract}

Keywords: copper-zinc manganite, lanthanum, alkali metals, synthesis, nanostructured particles of X-ray phase analysis.

\section{Introduction}

The development of modern branches of science and technology is impossible without directed synthesis and research of materials with a set of necessary physical and chemical properties. Currently, the object of close attention of researchers is oxide materials with semiconducting, ferroelectric, piezoelectric and pyroelectric and superconducting properties and high mixed (electronic and ionic or metallic) conductivity. These materials include rare-earth manganites of the composition $\mathrm{R}_{1-\mathrm{x}} \mathrm{M}_{\mathrm{x}} \mathrm{MnO}_{3-\delta}(\mathrm{R}-$ rareearth elements, $\mathrm{M}-$ is a divalent cation). The discovery of a giant negative resistance in manganites (19931994) of the $\mathrm{La}(\mathrm{Ca}, \mathrm{Ba}) \mathrm{MnO} 3$ type with a perovskite structure was the beginning of work in the field of synthesis and research of new, previously unknown compounds formed in systems consisting of oxides of rare-earth elements, alkaline earth metals. and manganese (III).

Materials with colossal reluctance can be used as magnetic field sensors, high-density magnetic recording heads, displacement and temperature sensors. Compounds based on oxides of the transition $3 d-$ and $4 f$-elements with a perovskite structure or close to it (manganites, zincates, cuprates, nickelates, cobaltites of rare-earth metals) and their solid solutions with oxides of the alkali and alkaline earth metals were widely used due to their interesting properties such as a high value of an electrical conductivity in a significant temperature range, the electronic conductivity character (semiconductor $n$ - or $p$-type or metal), the magnetic and superconducting properties, etc. [1-7].

In addition, many publications of scientists from near and far abroadand also our papers on synthesis and investigation of the physicochemical properties of compounds of the above mentioned classes were summarized in our monographs [8-12]. It should also be noted that manganese-based compounds are widely applied in the ferroalloy industry $[13,14]$.

\section{Experimental technique}

In order to accumulate various unique properties of the individual compounds in a single complex, i.e. combining of cuprates, zincates and manganites as the copper-zinc manganites, the phases of composition of $\mathrm{LaMe}_{2}{ }_{2} \mathrm{CuZnMnO}_{6}\left(\mathrm{Me}^{\mathrm{I}}-\mathrm{Li}, \mathrm{Na}, \mathrm{K}\right)$ were synthesized. A similar work on the synthesis of lanthanum and sodium cobalt-copper manganite was published by us in [15]. To synthesize $\mathrm{LaMe}_{2}^{\mathrm{I}} \mathrm{CuZnMnO}_{6}$ compounds 
the source materials were oxides of lanthanum $\mathrm{La}_{2} \mathrm{O}_{3}$ ("puriss. spec."), copper $\mathrm{CuO}$, zinc $\mathrm{ZnO}$, manganese $\mathrm{Mn}_{2} \mathrm{O}_{3}$, carbonates of $\mathrm{Li}_{2} \mathrm{CO}_{3}, \mathrm{Na}_{2} \mathrm{CO}_{3}$ and $\mathrm{K}_{2} \mathrm{CO}_{3}$ ("p.a."), their stoichiometric quantities were milled well and mixed up in an agate mortar, then mixtures in the alundumcrucibles were annealed in SNOL furnace at a temperature of $800{ }^{\circ} \mathrm{C}$ for $10 \mathrm{~h}$ in the air. Then they were cooled to a room temperature, mixed and milled. Further they were heat-treated at $1200{ }^{\circ} \mathrm{Cfor} 20 \mathrm{~h}$. The mixtures were cooled again to a room temperature, milled and mixed. To obtain the stable equilibrium phases at low temperatures, the mixtures were annealed at $400{ }^{\circ} \mathrm{Cfor} 10 \mathrm{~h}$.

Further, to obtain the nanostructured particles of the copper-zinc manganites, their polycrystalline samples were mixed to the nanostructured particles on Retsch MM301 vibration mill (Germany) at the Karaganda Technical University. The particle sizes were determined on an electron microscope Mira 3 LMU, Tescan (Fig. 1) and an atomic-force microscope JSPM-5400 Scanning Probe Microscope "JEOL" (Japan) at the E.A. Buketov Karaganda University (Fig. 2).

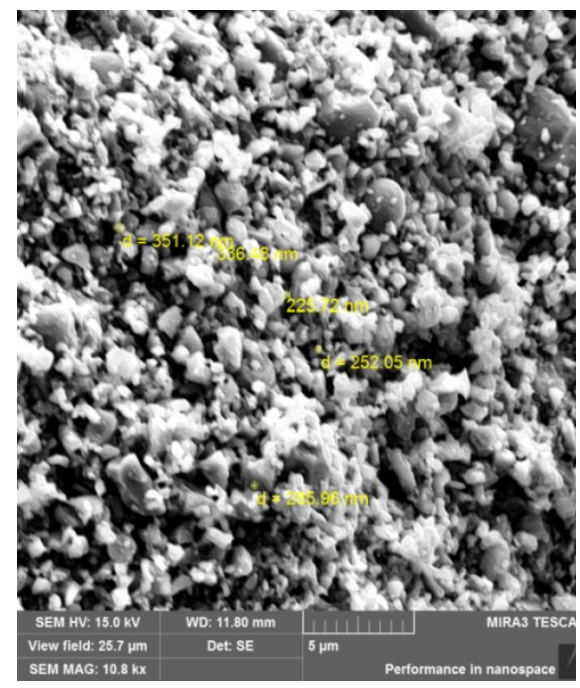

$\mathrm{LaLi}_{2} \mathrm{CuZnMnO}_{6}$

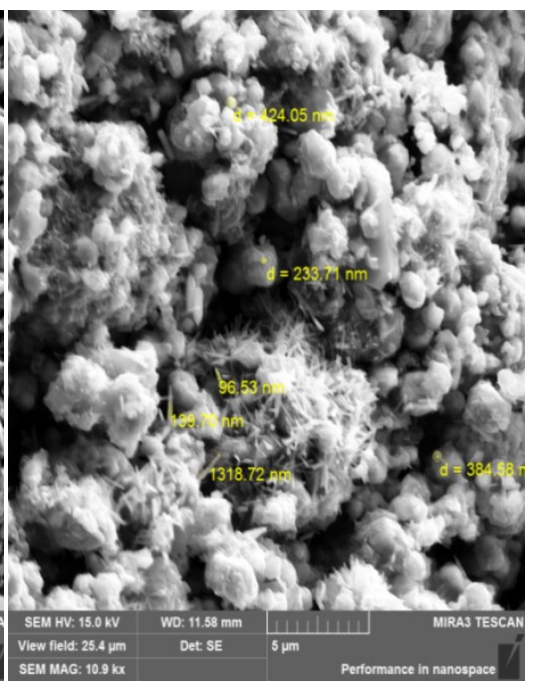

$\mathrm{LaNa}_{2} \mathrm{CuZnMnO}_{6}$

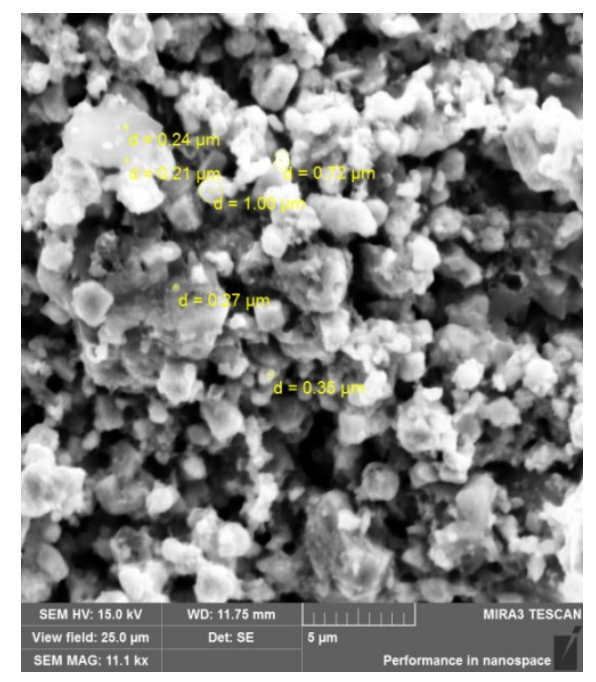

$\mathrm{LaK}_{2} \mathrm{CuZnMnO}_{6}$

Fig. 1. SEM images

The data of Figure 1 demonstrates that $\mathrm{LaLi}_{2} \mathrm{CuZnMnO}_{6}$ is characterized with the particle sizes in the range of 226-285 nm, $\mathrm{LaNa}_{2} \mathrm{CuZnMnO}_{6}-97-384 \mathrm{~nm}$ and $\mathrm{LaK}_{2} \mathrm{CuZnMnO}_{6}-210-650 \mathrm{~nm}$.

The X-ray analysis of the obtained nanostructured particles was performed on DRON-2.0. The conditions of exposure: $\mathrm{CuK}_{\alpha}$ - radiation, $\mathrm{U}=30 \mathrm{kV}, \mathrm{I}=10 \mathrm{~mA}$, a rotation speed - 100 pulses per second, time constant $\tau=5 \mathrm{sec}$, an angle interval $-2 \theta$ from 10 to $90^{\circ}$. Intensity of the diffraction maxima was estimated on 100-point scale. The X-ray patterns were indicated by an analytical method [16]. Density of each compound was measured 4-5 times and the results were averaged. The procedure and calculating formula were taken from [17]. The table below shows results on assignment of indices of X-ray patterns of the nanostructured copper-zinc manganites.

\section{Results and discussion}

The obtained nanoscale particles of the copper-zinc manganites can be classified as the nanostructured. Referring to recommendations of the 7th International conference on nanotechnologies (Germany, Wiesbaden, 2004), the following types of nanomaterials were distinguished: the nanoporous structures, nanoparticles, nanotubes and nanofibers, nanodispersions (colloids), nanostructured surfaces and films, nanocrystals and nanoclusters. According to [18], if a nanoparticle has a complex shape and structure, then a linear size of a particle as a whole are not studied, but a size of its structural element is exanimated as characteristic. Such particles are generally referred to as the nanostructured particles, and their linear sizes can be significantly larger than $100 \mathrm{~nm}$.

Based on the assignment of indices of X-ray patterns of the nanostructured copper-zinc manganites, it was defined that they crystallize in the cubic syngony with the following parameters of lattice: $\mathrm{LaLi}_{2} \mathrm{CuZnMnO}_{6}-\mathrm{a}=13.94 \pm 0.02 \AA, \mathrm{V}^{\mathrm{o}}=2708.87 \pm 0.06 \AA^{3}, \mathrm{Z}=4, \mathrm{~V}_{\text {elec.cell }}^{\mathrm{o}}=677.22 \pm 0.02 \AA^{3}, \rho_{\text {roent. }}=4.31$ 
$\mathrm{g} / \mathrm{cm}^{3} ; \rho_{\text {pick. }}=4.28 \pm 0.02 \mathrm{~g} / \mathrm{cm}^{3} ; \mathrm{LaNa}_{2} \mathrm{CuZnMnO}_{6}-\mathrm{a}=14.82 \pm 0.02 \AA, \mathrm{V}^{\mathrm{o}}=3254.95 \pm 0.06 \AA^{3}, \mathrm{Z}=4, \mathrm{~V}_{\text {elec.cell }}^{\mathrm{o}}$ $=813.74 \pm 0.02 \AA^{3}, \rho_{\text {roent. }}=4.13 \mathrm{~g} / \mathrm{cm}^{3} ; \rho_{\text {pick }}=4.09 \pm 0.05 \mathrm{~g} / \mathrm{cm}^{3} ; \mathrm{LaK}_{2} \mathrm{CuZnMnO}_{6}-\mathrm{a}=15.30 \pm 0.02 \AA, \mathrm{V}^{\mathrm{o}}=$ $3581.58 \pm 0.07 \AA^{3}, Z=4, V_{\text {elec.cell }}^{0}=895.39 \pm 0.02 \AA^{3}, \rho_{\text {roent. }}=3.91 ; \rho_{\text {pick. }}=3.88 \pm 0.01 \mathrm{~g} / \mathrm{cm}^{3}$. The errors of the parameters " a " are determined by averaging all the diffraction lines $(\mathrm{d}, \AA)$ established on the X-ray images of the studied compounds, for $\mathrm{LaLi}_{2} \mathrm{CuZnMnO}_{6}$ out of 17 maxima of the diffraction lines, for $\mathrm{LaNa}_{2} \mathrm{CuZnMnO}_{6}$ out of 13 , for $\mathrm{LaK}_{2} \mathrm{CuZnMnO}_{6}$ out of $15 \mathrm{~d}, \AA$.
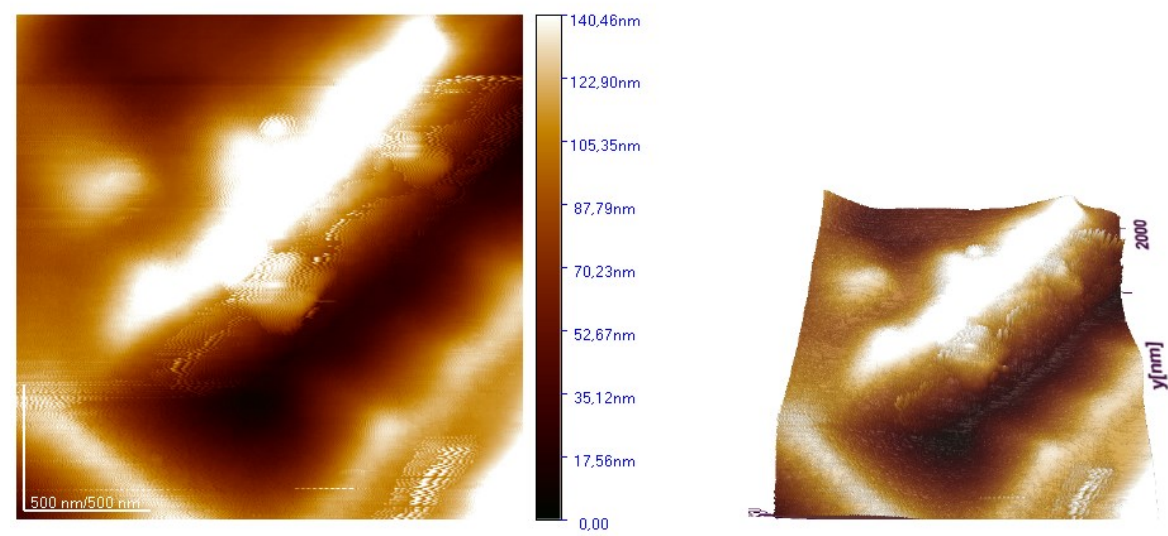

$\mathrm{LaLi}_{2} \mathrm{CuZnMnO}_{6}$
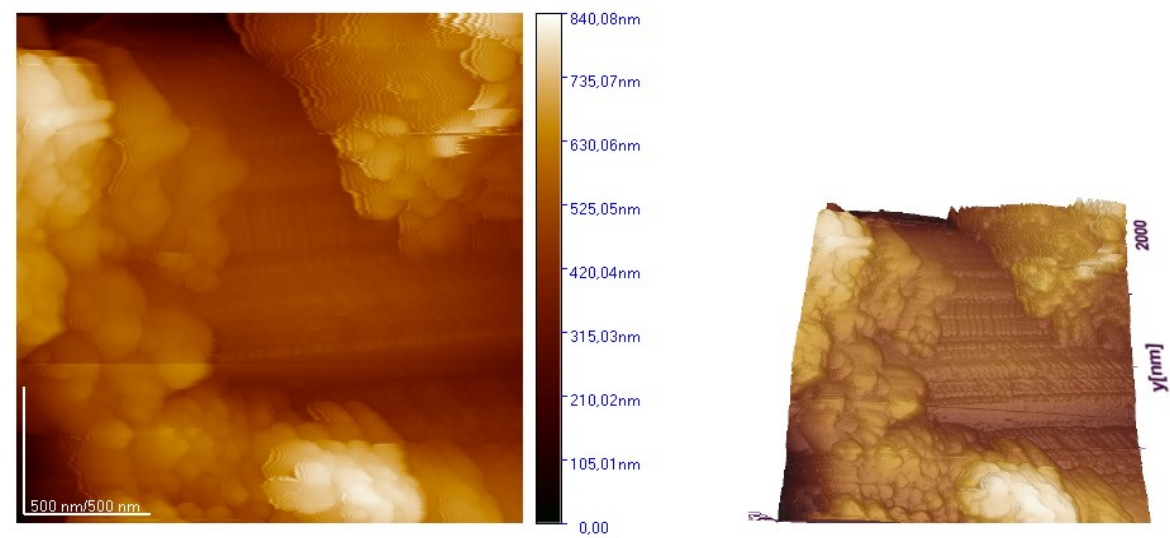

$\mathrm{LaNa}_{2} \mathrm{CuZnMnO} 6$
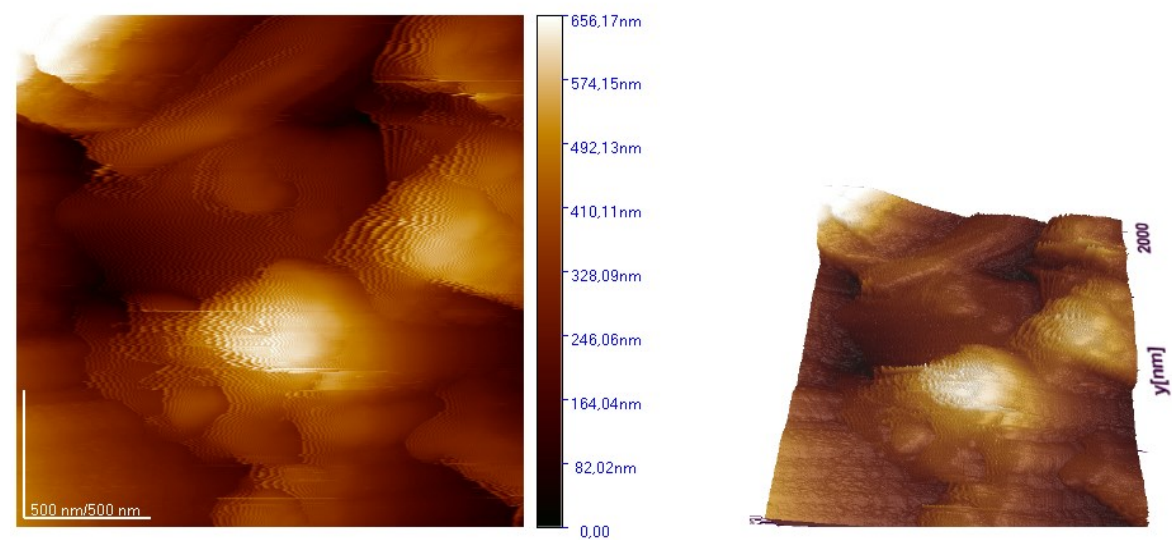

$\mathrm{LaK}_{2} \mathrm{CuZnMnO}$

Fig. 2. Atomic-force microscopic image and 3D surfaces 
Table 1. Assignment of indices of X-ray patterns of the nanostructured of $\mathrm{LaLi}_{2} \mathrm{CuZnMnO}_{6}$ (I), $\mathrm{LaNa}_{2} \mathrm{CuZnMnO}_{6}$ (II) and $\mathrm{LaK}_{2} \mathrm{CuZnMnO}_{6}$ (III)

\begin{tabular}{|c|c|c|c|c|}
\hline $\mathrm{I} / \mathrm{I}^{0}$ & $\mathrm{~d}, \AA$ & $10^{4} / \mathrm{d}^{2}$ (experimental) & $\mathrm{hkl}$ & $10^{4} / \mathrm{d}^{2}$ (calculated) \\
\hline \multicolumn{5}{|c|}{$\mathrm{LaLi}_{2} \mathrm{CuZnMnO}_{6}$} \\
\hline 38 & 3.882 & 663.6 & 511 & 664.0 \\
\hline 18 & 2.865 & 1218 & 710 & 1229 \\
\hline 100 & 2.749 & 1323 & 721 & 1327 \\
\hline 14 & 2.509 & 1588 & 810 & 1598 \\
\hline 23 & 2.449 & 1667 & 420 & 1671 \\
\hline 12 & 2.367 & 1785 & 830 & 1794 \\
\hline 22 & 2.245 & 1984 & 900 & 1991 \\
\hline 78 & 1.939 & 2660 & 10.2 .2 & 2655 \\
\hline 6 & 1.864 & 2878 & 10.4 .1 & 2875 \\
\hline 8 & 1.725 & 3361 & 10.6 .1 & 3368 \\
\hline 6 & 1.697 & 3472 & 11.4 .2 & 3466 \\
\hline 37 & 1.586 & 3975 & 12.3 .3 & 3982 \\
\hline 12 & 1.433 & 4870 & 14.1 .1 & 4867 \\
\hline 16 & 1.375 & 5289 & 14.3 .1 & 5295 \\
\hline 14 & 1.361 & 5399 & 13.5 .5 & 5383 \\
\hline 12 & 1.229 & 6620 & 16.3 .3 & 6612 \\
\hline 14 & 1.222 & 6697 & 16.4 .0 & 6686 \\
\hline \multicolumn{5}{|c|}{$\mathrm{LaNa}_{2} \mathrm{CuZnMnO}_{6}$} \\
\hline 14 & 3.902 & 656.8 & 520 & 657.0 \\
\hline 100 & 2.757 & 1316 & 730 & 1314 \\
\hline 11 & 2.604 & 1475 & 740 & 1472 \\
\hline 10 & 2.525 & 1568 & 743 & 1562 \\
\hline 13 & 2.475 & 1632 & 822 & 1631 \\
\hline 11 & 2.321 & 1856 & 910 & 1857 \\
\hline 16 & 2.247 & 1980 & 664 & 1993 \\
\hline 35 & 1.945 & 2643 & 10.4 .1 & 2650 \\
\hline 7 & 1.737 & 3314 & 981 & 3307 \\
\hline 34 & 1.572 & 4046 & 13.3 .1 & 4054 \\
\hline 9 & 1.475 & 4596 & 11.9 .1 & 4598 \\
\hline 17 & 1.374 & 5297 & 15.3 .0 & 5300 \\
\hline 15 & 1.229 & 6620 & 16.6 .0 & 6613 \\
\hline \multicolumn{5}{|c|}{$\mathrm{LaK}_{2} \mathrm{CuZnMnO}_{6}$} \\
\hline 17 & 3.890 & 660.8 & 440 & 661.0 \\
\hline 100 & 2.756 & 1316 & 800 & 1322 \\
\hline 15 & 2.600 & 1479 & 822 & 1487 \\
\hline 13 & 2.526 & 1567 & 662 & 1569 \\
\hline 16 & 2.364 & 1789 & 655 & 1776 \\
\hline 14 & 2.249 & 1977 & 844 & 1982 \\
\hline 50 & 1.945 & 2643 & 880 & 2643 \\
\hline 7 & 1.740 & 3303 & 12.4 .0 & 3304 \\
\hline 8 & 1.624 & 3792 & 12.6 .2 & 3800 \\
\hline 30 & 1.588 & 3965 & 888 & 3965 \\
\hline 7 & 1.459 & 4698 & 15.1 .1 & 4688 \\
\hline 5 & 1.410 & 5630 & 12.10 .0 & 5039 \\
\hline 17 & 1.375 & 5289 & 16.0 .0 & 5286 \\
\hline 4 & 1.295 & 5963 & 16.4 .4 & 5947 \\
\hline 13 & 1.229 & 6620 & 17.4 .4 & 6629 \\
\hline
\end{tabular}


A good fit of the experimental and calculated values of $10^{4} / \mathrm{d}^{2}$ (Table 1 ), the X-ray and picnometric densities points out the correctness and assurance of results of assignment of indices. Based on [16], the experimentally determined density refers to a real crystal and it should be slightly below than ideal. This statement also confirms that the pycnometric (experimental) densities of our obtained copper zinc manganites are relatively lower than the X-ray (ideal).

By analogy of $[8,19]$, the synthesized copper-zinc manganitescan be assigned to the space group Pm $3 m$ of perovskite. In connection with raising the sizes of the ionic radiuses in a row of $\mathrm{Li}^{+} \rightarrow \mathrm{Na}^{+} \rightarrow \mathrm{K}^{+}$, the values of «a» parameter is increased, and the values of volumes of the crystalline lattices and the elementary cells are increased in a row ofLaLi $\mathrm{CuZnMnO}_{6} \rightarrow \mathrm{LaNa}_{2} \mathrm{CuZnMnO}_{6} \rightarrow \mathrm{LaK}_{2} \mathrm{CuZnMnO}_{6}$.

\section{Conclusion}

The polycrystalline copper-zinc manganites of the composition of $\operatorname{LaLiMe}_{2}^{\mathrm{I}} \mathrm{CuZnMnO}_{6}\left(\mathrm{Me}^{\mathrm{I}}-\mathrm{Li}, \mathrm{Na}\right.$, $\mathrm{K}$ ) were first synthesized by a method of the ceramic technology. By milling them on a vibration mill, their nanostructured particles were obtained. It was found that all obtained nanostructured copper-zinc manganites crystallize in the cubic syngony. Their lattice parameters, X-ray and pycnometric densities were determined.

It was found that with an increase in the ionic radii in the series $\mathrm{Li}$ and $\mathrm{K}$, the lattice parameters of the studied manganites increase. The research results work make a certain contribution to the inorganic materials science, nanotechnology, radiography and crystal chemistry of nanostructured inorganic compounds and serve as the basis for further research in order to identify valuable and promising physicochemical properties of these new obtained nanomaterials.

\section{Acknowledgments}

\section{This research was funded by the Science Committee of the Ministry of Education and Science of the Republic of Kazakhstan (Grant No. AP08855601).}

\section{REFERENCES}

1 Tretyakov Yu.D., Brylyov O.A. New generations of inorganic functional materials. Journal of the Russian Chemical Society named after D.I. Mendeleev, 2000, Vol. 44, No. 4, pp. 10-16. [in Russian].

2 Grunberg P.A. From spin waves to giant magnetoresistance and beyond. Physics-Uspekhi, 2008, Vol. 178, Iss. 12, pp. 1349-1358. DOI: 10.3367/ufnr.0178.200812g.1349. [in Russian].

3 Erin Yu. Substance with high value of dielectric capacitivity was found. Chemistry and Chemists, Part 1, 2009. Available at the: http://chemistry-chemists.com/N1_2009/16-22.pdf [in Russian].

4 Kuznetsov M.V., Morozov Yu.G., Belousovà O.V., Ortega D. Ferromagnetic nanoparticles of $\mathrm{Zn} / \mathrm{ZnO}$. Inorganic Materials, 2014, Vol. 50, No. 4, pp. 399-409. DOI: 10.7868/s0002337x14040101. [in Russian].

5 Solin N.I., Naumov S.V. Magnetic and electrical properties of weakly doped manganese-deficient $\mathrm{La}_{1 \mathrm{x}} \mathrm{Ca}_{\mathrm{x}} \mathrm{Mn}_{1 \mathrm{z}} \mathrm{O}_{3}$ manganites. Journal of Experimental and Theoretical Physics, 2013, Vol. 116, No. 1, pp. 145-158.

6 Nagaev E.L. Physics of magnetic semiconductors. Moscow, Nauka, 1983, 220 p. [in Russian].

7 Perekalina T.M., Sivokon T.A., Cherkezyan S.A. et al. Magnetic and electrical properties of $\mathrm{La}_{1-\mathrm{x}} \mathrm{Sr}_{\mathrm{x}} \mathrm{MnO}_{3}$. Physics of the Solid State, 1989, Vol. 31, No. 9, pp. 87-89. [in Russian].

8 Kasenov B.K., Kasenova Sh.B., Sagintaeva Zh.I., et al. Double and triple manganites, ferrites and chromites of alkali, alkaline earth and rare earth metals. Moscow, 2017, 416 p. [in Russian].

9 Kasenov B.K., Kasenova, Sh.B., Sagintaeva, Zh.I., et al. Physical properties of manganites. Karaganda, 2017, 123 p.

10 Kasenov B.K., Kasenova, Sh.B., Sagintaeva Zh.I., Kuanyshbekov E.E. New materials based on oxides of s-, $d$ - and f-elements. Karaganda, 2017, 117 p. [in Russian].

11 Ermaganbetov K.T., Chirkova L.V., Kasenov B.K. Physics of magnetic and kinetic phenomena in manganites of lanthanides. Karaganda, 2017, 251 p.

12 Kasenov B.K., Kasenova Sh.B., Sagintaeva Zh.I., et al. New substituted polycrystalline and nanodimensional manganites. Karaganda, Ecozhan, 2019, 108 p. [in Russian].

13 Baisanov S.O., Gabdulin G.G., Takenov T.D. About organization of production of manganese ferroalloy from Kazakhstan raw materials. Steel, 1997, Vol. 7, pp. 29-32. [in Russian].

14 Baisanov S.O., Takenov T.D., Tolymbekov M.Zh. About conditions of selective reduction in the $\mathrm{Fe}-\mathrm{Mn}-\mathrm{O}$ system]. Bulletin of the Karaganda University. Chemistry series, 2005, No. 4(40), pp. 65-70. [in Russian].

15 Kassenova Sh.B., Sagintayeva Zh.I., Kassenov B.K., Kuanyshbekov E.E, Bekturganov Zh.S., Zeinidenov A.K. Electrophysical characteristics of nanodimensional cobalte-cuprate-manganite $\mathrm{LaNa}_{2} \mathrm{CoCuMnO}_{6}$ and nickelitecuprate-manganite $\mathrm{LaNa}_{2} \mathrm{NiCuMnO}_{6}$. Bulletin of the Karaganda University. Physics Series, 2020. No. 2(98), pp. 43-49.

16 Kovba L.M., Trunov V.K. X-ray phase analysis. Moscow, 1976, 256 p. [in Russian].

17 Kivilis S.S. Technique of measuring of the density of liquids and solids. Moscow, 1959, 191 p. [in Russian].

18 Tretyakov Yu.D. Challenges of nanotechnological development in Russia and abroad. Herald of the Russian Academy of Sciences, 2007, Vol. 77, No.1, pp. 15-21. DOI: 10.1134/s1019331607010030.

19 Vest A. Chemistry of solid state. Moscow, World, 1988, 588 p. [in Russian]. 